\title{
Marlene Priller
}

UNIVERSITY OF GRAZ,

University of Music and Performing Arts Graz

\section{An examination of Clara Schumann's musical salons and the research problems that occurred}

Clara and Robert Schumann were connected very closely to the culture of musical salons, not only in Germany but also in other European countries, such as Austria, France, Denmark and Russia. Musical salons within and outside Germany considerably influenced Clara Schumann's career not only in the beginning but also later; she even organised some salons together with her husband. The salons established by the Schumanns were particularly important institutions for young and ambitious musicians and composers.

In this article, the existent and non-existent source material will be discussed and by doing so the current state of research on this subject will be elaborated. The following part tries to give an idea of the characteristics of the private circles of Clara and Robert Schumann during their years of marriage and the years after Robert Schumann's death from 1856 to 1896 . The article will be concluded by a summary of what I found out during my research and will address several questions that arose while writing it.

\section{Existent and Non-existent Source Material}

Clara Schumann's life is documented very well, but unfortunately there is only limited literature dealing with her activities in musical salons. 
Veronica Beci's publication Musikalische Salons. Blütezeit einer Frauenkultur (2000) deals, among other topics, with Clara Schumann's activities in musical salons and with salons organised by Clara Schumann. However, this publication has to be handled carefully as there are no references in the text and only chosen sequences of Schumann's life are portrayed. Veronica Beci's lack of careful research will be discussed later. Some of her statements are wrong and some were put in a different context. Therefore, some of the sources are diaries, letters and memoires written by various authors. Since the year 2000 there has been a great number of books published on the life and work of Clara Schumann and on friends of Clara and Robert Schumann. Among these publications there are: Clara Schumann. Musik und Öffentlichkeit (2009) by Janina Klassen, Clara Schumann (2007) by Monica Steegmann and Fanny Hensel geb. Mendelssohn. Musikerin der Romantik (2007) by Peter Schleuning. The research done by these authors already deals with a lot of relevant sources for this article, for instance, the diaries of Fanny Hensel. Thus, these publications are of particular interest and value for me and this paper.

It is hardly possible to extract relevant information about this subject directly from Clara and Robert Schumann's diary entries or letters. The information we gained from the diary entries is that guests had come and music had been played, but they lack details. In some entries it is mentioned that the guests met in the evening ${ }^{1}$ and sometimes names of guests are mentioned. Moreover, they offer the information that they were visited and that they played together without inviting someone and sometimes they invited special guests for a soiree ${ }^{2}$ but they do not offer any finer details as mentioned before. Nevertheless, many entries are useful concerning several statements about soirees organised by friends and acquaintances. These statements are of particular interest, because they answer some questions of what Clara and Robert Schumann wanted their salons to be like and what they disapproved of. However, it remains challenging to gather information on this subject, as there is no literature focusing on these aspects.

1 See for example R. Schumann, Tagebücher, Vol. 2: 1836-1854, ed. by G. Nauhaus, Frankfurt am Main 1987, pp. 11, 135-136, 151.

2 The diary reports in December 1841 that a soiree with selected guests took place. R. Schumann, Tagebücher, op. cit., p. 197. 
Other important sources are the memoirs and diaries of other musicians or friends of Clara and Robert Schumann. One of these sources are the memoirs of the pianist Luise Adolpha Le Beau. ${ }^{3}$ These memoires tell us about Clara Schumann's character and personality. However, we have to be careful with that portrayal of her, as it seems that Luise Adolpha Le Beau and Clara Schumann were rivals ${ }^{4}$ and for this reason biased descriptions are possible. One has to be particularly careful with this kind of subjective and one-sided statements, when it is written and published by a competitive person. Another source may be the diaries of Ferdinand Hiller. Unfortunately, I do not have any access to these but for further research these diaries may be of interest and so could be the Leipzig-diaries of William Sterndale Bennett, which are in the making.

Another essential source is a biography of Clara Schumann that was published by Berthold Litzmann in three volumes. ${ }^{5}$ This biography is of crucial importance, as Clara's personal diaries about the years following 1844 were destroyed; only the so called "marriage diaries", 6 which date up to 1844 still exist. Some diaries and letters were systematically destroyed during Clara Schumann's lifetime and also later, after her death, by her descendants. Litzmann's biography was published shortly after the turn to the $2 \mathrm{O}^{\text {th }}$ century and at this time, he still had access to some documented information and sources, which do not exist anymore. After his publication the remainder of the diaries was destroyed. Therefore, the biography contains information we are nowadays unable to access anywhere, and hence it is of significant relevance to my research. ${ }^{7}$

3 L.A. Le Beau, Lebenserinnerungen einer Komponistin, Baden-Baden 1910, Reprint: Baden-Baden 1999.

4 See C. de Vries, Die Pianistin Clara Wieck-Schumann. Interpretation im Spannungsfeld von Tradition und Individualität, Mainz 1996, p. 360.

5 B. Litzmann, Clara Schumann. Ein Künstlerleben. Nach Tagebüchern und Briefen, 3 volumes, Leipzig 1902-1910.

6 G. Nauhaus, I. Bodsch (eds.), Robert und Clara Schumann Ehetagebücher 18401844, 2. edition, Bonn 2013.

7 During my visit at the archive in Zwickau last year, I had the opportunity to talk to its employee who told me that some diaries and letters were systematically destroyed during Clara's lifetime and after her death by her descendants. 


\section{The Musical Salons of the Schumann's}

The first circle was formed by Clara Schumann in the 1840 os in Leipzig after she had gotten married to Robert Schumann. They chose their house in Leipzig because of its social opportunities and artistic presentation. The salon had a square shape, three big windows and accommodated up to 30 people. ${ }^{8}$ It has been preserved and is still used for concerts.

As mentioned before, Clara and Robert Schumann's salons demonstrated an important institution for ambitious musicians and composers. The circles in Leipzig were not used to communicating, but rather to intensive and systematic studies of music. The focus was on the music of Robert Schumann and of Felix Mendelssohn Bartholdy. ${ }^{9}$ In particular during the first year after their marriage the Schumanns received visits from many high-ranking and influential musicians such as the Dutch composer Johann Verhulst; the German composer Felix Mendelssohn Bartholdy; their long-time friend the pianist and teacher Ernst Ferdinand Wenzel; the British composer William Sterndale Bennett; Walther von Goethe, who was Johann Wolfgang von Goethe's grandson; the German-Russian composer Adolph Henselt; the young American pianist Harriett Parish; the Norwegian violinist Ole Bull, and many more. ${ }^{10}$ Occasional soirees took place, but sometimes Clara was reluctant to participate. ${ }^{11}$ The very first soiree took place in October 1840. About 20 guests had come. Clara played trios by Mendelssohn and Moscheles and Elise List sang songs by Robert Schumann and Felix Mendelssohn. ${ }^{12}$ Unfortunately there are no more details mentioned in the diary.

Nils Wilhelm Gade's career was of special importance to Clara Schumann, thus she supported him especially. For instance, she introduced Gade to Mendelssohn Bartholdy. After this encounter, Mendelssohn Bartholdy organised the performance of Gade's Symphony

8 See J. Klassen, Clara Schumann. Musik und Öffentlichkeit, Köln 2009 (Europäische Komponistinnen 3), p. 181.

9 See V. Beci, Musikalische Salons. Blütezeit einer Frauenkultur, Zürich 200o, p. 68.

10 See N.B. Reich, Clara Schumann Romantik als Schicksal. Eine Biographie, Hamburg 1991, pp. 130-131.

11 See M. Steegmann, Clara Schumann, Hamburg 2007, p. 64.

12 See R. Schumann, Tagebücher, op. cit., p. 113. 
No. 1 in $C$ minor in a concert. ${ }^{13}$ In the 1840 os it became obvious that Clara Schumann's main ambition was to support young artists and to enhance their careers by using her social network.

In 1844 the whole family moved to Dresden. According to Veronica Beci it was not possible for Clara and Robert Schumann to build a circle in Dresden. ${ }^{14}$ One reason could be that their circle of friends was not big enough, but also Robert's visibly declining state of health and his music, which was ill-reputed as romantic and modern, display possible reasons. There were hardly any supporters in Dresden; however, this was also due to the fact that Robert made no secret of his low opinion of his so-called composing colleagues. ${ }^{15}$ Yet there is a reason to doubt that statement by Veronica Beci even though Nancy Reich provides evidence for it. During the time spent in Dresden from 1844 to 1850 Clara and Robert were regularly visited by the composers Ferdinand Hiller, Nils Wilhelm Gade, the violinist Ferdinand David and many others. In Robert Schumann's diary there are entries in which he calls these meetings "Kränzchen" ${ }^{16}$ which means private soirees. In addition to that, Clara and Robert Schumann indeed got visits and organised musical salons at their home. According to these sources, these meetings had a character of private and domestic musical events.

In 1847, Clara Schumann stayed in Berlin, while the rest of her family resided in Dresden. In Berlin she was introduced to Fanny Hensel, who became a close friend of hers. ${ }^{17}$ This is also why Clara Schumann was invited to the regularly held "Sonntagsmusiken" of Fanny Hensel. ${ }^{18}$ On Sundays, after the opening of the summer season, Fanny Hensel used to invite some of her friends in order to make music. ${ }^{19}$ However, Fanny Hensel's "Sonntagsmusiken" were normally private, but sometimes also semi-public events in contrast to Clara Schumann's parties. Fanny Hensel's salon was much bigger and accommodated up

13 See V. Beci, Musikalische Salons..., op. cit., p. 68.

14 Ibid.

15 See N.B. Reich, Clara Schumann Romantik als Schicksal, op. cit., pp. 154-156.

16 See R. Schumann, Tagebücher, op. cit.; diary entries between the years 1844 and 1850.

17 Fanny Hensels diary reports on March 20th in 1847 that Clara visited Fanny nearly every day and that Fanny became fond of Clara. See F. Hensel, Tagebücher, ed. by H.-G. Klein and R. Evers, Wiesbaden 2002, p. 274.

18 See V. Beci, Musikalische Salons..., op. cit., p. 68.

19 See P. Wilhelmy-Dollinger, Die Berliner Salons, Mit historisch-literarischen Spaziergängen, Berlin 2000, p. 151. 
to 200 guests. ${ }^{20}$ Clara was delighted by these soirees. Due to sobriety, the severe discipline and the rigid organisation, it was possible to witness masterful performances. Fanny Hensel's soirees created the basis for Clara Schumann's own soirees ${ }^{21}$ in the coming years. Unfortunately, Veronica Beci does not give a more detailed description of Fanny Hensel's "Sonntagsmusiken". From Peter Schleuning we learn that many celebrities such as Giuditta Pasta, Pauline Decker, Franz Liszt, the painter Peter Cornelius and the nobility visited the "Sonntagsmusiken". Sometimes the "Sonntagsmusiken" took place in the morning. The repertoire consisted, among others, of pieces by Johann Nepomuk Hummel, Ferdinand David, Ludwig van Beethoven, Felix Mendelssohn - the music to Walpurgisnacht, Sommernachtstraum Mozart's Requiem, as well as fragments of Goethe's Faust and Hero und Leander by Fanny Hensel ${ }^{22}$. Considering the repertoire and the prominent guests it becomes more possible that the "Sonntagsmusiken" were practised with discipline. Otherwise it would not had been possible to perform Mozart's Requiem, for example. Masterful performances were very important for Fanny Hensel and her brother. Fanny Hensel felt torment when Giuditta Pasta's low-pitched tones were intoned between an eighth tone and a quarter tone too low. ${ }^{23}$

The next opportunity to organise regular concerts at home was offered to Clara and Robert Schumann in 1850 in Düsseldorf. They moved there because Robert followed Ferdinand Hiller as a conductor. In contrast to Paris, where several prominent musical salons had existed before, the salon of the Schumann's in Düsseldorf was the only prominent one. ${ }^{24}$ The Schumanns had a very convivial household. Often in the evening music had been played and on June $28^{\text {th }}$, 1842 the diary reports that acquaintances came and that they were much exhilarated. The local prominence, such as the poet Wolfgang Müller von Königswinter, the painters Hildebrand, Eduard Bendemann, Ernst Rietschel and Ludwig Richter, Ferdinand Hiller and Robert's student, the violinist Wilhelm Joseph von Wasielewski were invited to the home of Clara and Robert Schumann. Clara used to call these

20 See P. Schleuning, Fanny Hensel geb. Mendelssohn. Musikerin der Romantik, Wien 2007, p. 211.

21 See V. Beci, Musikalische Salons..., op. cit., p. 68.

22 See P. Schleuning, Fanny Hensel geb. Mendelssohn..., op. cit., pp. 208-211.

23 Ibid., p. 208.

24 See V. Beci, Musikalische Salons..., op. cit., p. 63. 
events "Kleine Musik". At these events Clara performed Robert's new compositions in front of a selected audience. By organising them, she wanted to provide soirees that were as well planned and structured as the soirees organised by Fanny Hensel, which were mentioned before. However, this did not work out the way it should have, mainly because the laymen, who were employed, were not as strict with punctuality and regular attendance. ${ }^{25}$ Nonetheless, the Schumanns employed professional performers for some of the private musical events that took place at their home. There is an anecdote about the violinist Wilhelm Wasielewski, in which he was invited to a private soiree at Schumann's in 1852. Allegedly, Robert Schumann opened the door wearing a suit. Since the violinist Wasielewski was underdressed, he was sent home to change his clothes. ${ }^{26}$ But not only were the laymen not as strict with punctuality, also some of the prominent guests failed to attend on time. In February 1851 Clara complained that her guests including the painter Hildebrand and the poet Müller von Königswinter were too late too often. ${ }^{27}$ The soirees should be practised with discipline and respect and the musicians should be dressed appropriately; that had been very important to Clara and Robert Schumann, as they saw their soirees as a cultivation of music. They could not stand people talking and laughing instead of listening to and concentrating on the music. Supporting articles can be found in Berthold Litzmann's biography of Clara Schumann. According to Litzmann, Clara Schumann once noted: 'Kränzchen bei Hildebrands, Robert war sehr bös, weil so viel geschwatzt wurde. Der gute Hildebrand an der Spitze. Das ist eigen hier, zum Schwatzen haben sie immer Leben genug, zum Singen aber nicht. ${ }^{\text {'28 }}$ The parties at Schumanns were animated in 1853 by the violinist Joseph Joachim and the composers Johannes Brahms and Otto Julius Grimm. Additionally, Clara and Robert Schumann organised

25 See V. Beci, Musikalische Salons..., op. cit., pp. 68-69; see K. Höcker, Clara Schumann. Die große Pianistin ihrer Zeit. Die Lebensgefährtin Robert Schumanns. Die Freundin von Johannes Brahms, Berlin 1975, pp. 72, 86; see R. Schumann, Tagebücher, op. cit., p. 229 as well.

26 See J. Klassen, Clara Schumann, op. cit., p. 185.

27 B. Litzmann, Clara Schumann. Ein Künstlerleben. Nach Tagebüchern und Briefen, Vol. 2: Ehejahre 1840-1856, Leipzig 1920, p. 234.

28 "Party at Hildebrand's, Robert was very angry because there was so much chatter. Meaning that their host was one of the most talkative people. That is peculiar here; they always have enough life(-time) to chat, but not to sing." Ibid., p. 235. 
'Singekränzchen' (since September 1851) and 'Quartettkränzchen' (since November 1851), but these were not held for a long time. It seems that the 'Singekränzchen' and 'Quartettkränzchen' were not liked as much. ${ }^{29}$

Even though the parties of the Schumann couple were said to be very strict, academic and little entertaining, there is again doubt that they really were as strict as it is believed by Veronica Beci, due to Robert Schumann's diary entries. On December $15^{\text {th }}, 1843$ the diary reports that there had been an amusing get-together at Schumann's, where all the guests were dancing until late at night. They enjoyed themselves as if they were at one of the greatest balls. Among the guests were Gade, David, the Frege's and Hiller. Clara played with Gade a Sonata for violin and piano and with Hiller the overture to Waldnymphe by William Sterndale Bennett. ${ }^{30}$ This entry gives reason to question the reported strictness of the parties by Veronica Beci. Moreover, this diary entry is not the only evidence for less strictness. On October $28^{\text {th }}, 1853$ a private soiree took place at Schumann's in honour of Joseph Joachim. Among its guests there were Bettine von Arnim, the Hasenclevers, the Schadows $^{31}$ and the Hammers. It is reported that all the guests and the hosts made a lot of music, that fairy tales were told and that this was not the first time they told fairy tales at one of their parties. ${ }^{32}$ Unfortunately, this report lacks details and so we do not know what was played and which fairy tales were told. Once Theodor Kirchner wrote in a letter to his friend Blanka Amsler that he spent "[...] selige Stunden [...] Es wurde viel Musik gemacht. Mit Clara spielte ich vierhändig eine neue Sinfonie von [Robert] Schumann. Von mir wurden Lieder gesungen., ${ }^{33}$ This letter gives reason to doubt the reported strictness as well.

29 See V. Beci, Musikalische Salons..., op. cit., p. 69; see R. Schumann, Tagebücher, Vol. 3: Haushaltsbücher, ed. by G. Nauhaus, Leipzig 1982, pp. 571, 576 as well. The „Singekränzchen“ was mentioned only once and the „Quartettkränzchen“ twice.

30 See R. Schumann, Tagebücher, op. cit., p. 274.

31 Richard Hasenclever (1813-1876) was a writer, an amateur composer and general practitioner of the Schumann's. Wilhelm von Schadow (1788-1862) was a painter and the cofounder of the Düsseldorfer Malerschule.

32 See B. Litzmann, Clara Schumann. Ein Künstlerleben. Nach Tagebüchern und Briefen, Vol. 2, op. cit., p. 284.

33 R. Hofmann, Die Beziehung zwischen Theodor Kirchner und Robert und Clara Schumann, in: "Neue Bahnen". Robert Schumann und seine Musikalischen Zeitgenossen, Mainz 2002, p. 157 (Schumann Forschungen 7). Theodor Kirchner spent "blissful hours [at Schumann's]. A lot of music had been played. With Clara I played Schumann's new sinfonia four-handed. Some of my songs had been sung." 
In 1857 , one year after Robert's death, Clara and her children moved to Berlin. In Berlin Clara became an important participant of the musical life of the city. Her friends met regularly in her house in order to make music. The repertoire consisted mainly of the music composed by Robert Schumann, Ignaz Moscheles, Johannes Brahms and Felix Mendelssohn Bartholdy. It was very important for the circles of Clara Schumann and the Mendelssohns to distribute the latest Romantic music, because the music of Robert Schumann had not become famous and Johannes Brahms had not composed his masterpieces yet. When Clara Schumann moved to Lichtenthal near Baden-Baden in 1863, she left a lot enthusiasm for the music of Brahms and Schumann behind. As a result, Berlin became a Mecca for the latest Romantic music in Germany. ${ }^{34}$ Countless people walked in and out of Clara's home in Lichtenthal. Many grand musicians, composers, virtuosos, singers, the Florentiner Quartetett, and many more visited Clara and they often played music. Friends and acquaintances such as Fanny Lewald, the painter Anselm Feuerbach and Ludwig Bamberger (Reichstag deputy) were invited to enjoy. Johannes Brahms was the most frequent visitor, but the musicians and composers Joseph Joachim, Julius Stockhausen, Anton Rubinstein, Aloys Schmitt, Theodor Kirchner and Hermann Levi visited Clara regularly too. ${ }^{35}$ In the 186 os the singer Pauline Viardot-Garcia lived in Baden-Baden as well. However, her soirees were completely different to those by Clara Schumann. On March $24^{\text {th }}$, 1862 Clara noted in her diary that she felt uncomfortable each time she visited Pauline Viardot-Garcia and that there was much restlessness. ${ }^{36}$ This entry supports the thesis of soirees as a cultivation of music which should be practised with discipline.

At the end of the 1870 os Clara moved to Frankfurt am Main to become a piano teacher at the conservatory. As she did in Leipzig and Berlin, Clara wanted to continue the "Kleine Musik"- circles in Frankfurt. Hence, she continued to organise such parties with the help of Johannes Brahms, Pauline Viardot-Garcia and Joseph Joachim. The guests and visitors met

34 See Veronica Beci, Musikalische Salons..., op. cit., p. 70.

35 See J.N. Naushaus, 1863-1873 Baden-Baden, in: Schumann-Portal, [online] http:// www.schumann-portal.de/Baden-Baden_1863-1873.html [accessed: 28.07.2016]; see E. Schumann, Claras Kinder. Erinnerungen, Köln 1995, pp. 133-134 as well.

36 See B. Litzmann, Clara Schumann. Ein Künstlerleben. Nach Tagebüchern und Briefen, Vol. 3: Clara Schumann und ihre Freunde, 3. edition, Frankfurt am Main 1910, pp. 116-117. 
at teatime at Myliusstraße 32. Among the guests who attended these private concerts were many of Clara Schumann's students, because of her teaching activity. On May $26^{\text {th }}, 1894$ a recital of Clara's students took place and some special guests, such as the composer Clementine Becker, were invited. ${ }^{37}$ What we see here is that Clara Schumann did not only support ambitious composers. As a result of inviting her piano students from the conservatory, it was possible for them to get in touch with many other musicians and composers as well as well-known people. It seems that these activities developed into studies with high educational demand. The main repertoire consisted of 'classical' music. Clara Schumann had a very conservative attitude regarding music. Once a student of hers dared to play a piece composed by Franz Liszt and as a consequence he was locked out of the circle. Clara Schumann wanted to distribute the classical and high romantic music and Liszt's music was apparently not a part of it..$^{38}$ Clara and Robert Schumann's daughter Eugenie reports in her memoires that Clara tried to encourage and support her children in their musical interests. Therefore, she initiated musical meetings and get-togethers with other musicians. It was important for Clara to study harmony and counterpoint. ${ }^{39}$ According to that some musical get-togethers had an educational demand. Despite her hearing impairment, Clara Schumann never lost the enjoyment of music and music-making. ${ }^{40}$ Ferdinand Schumann reports that Clara often played in private circles at home when he arrived in Frankfurt am Main in 1894 to live there. On November $10^{\text {th }}, 1894$ Johannes Brahms visited Clara Schumann and played his new clarinet sonata for the very first time. ${ }^{41}$

In contrast to the salons of many other women, for example the salon of Elisabeth von Herzogenberg or Luise Reichhardt, Clara Schumann's salons seemed to be strict and serious sometimes. One of her students, Luise Adolpha Le Beau, who was invited regularly, complained about the missing kindness and charm: "Liebenswürdigkeit besitzt sie nicht,

37 See F. Schumann, Erinnerungen an Clara Schumann, "Neue Zeitschrift für Musik", Vol. 84/9, p. 72.

38 See V. Beci, Musikalische Salons..., op. cit., pp. 71, 168-169.

39 See E. Schumann, Claras Kinder..., op. cit., p. 210.

40 U. Kienzle, Robert und Clara Schumann in Frankfurt, Frankfurt am Main 2010 (Mäzene, Stifter Stadtkultur Schriften der Frankfurter Bürgerstiftung und der Ernst Max von Grundelius-Stiftung 8), p. 165.

41 See F. Schumann, Erinnerungen an Clara Schumann, op. cit., p. 70. 
sagt alles so ungeduldig, selbst brutal, daß ich leider wenig Sympathie für sie behalten kann." ${ }^{2}$ Clara Schumann did not have the expected admiration a typical salonnière would have had. Maybe this circumstance was one of the reasons why her activities sometimes lacked amusement. Unfortunately, Veronica Beci ignored the fact that this quotation originates from a different context. The mentioned statement was said during a piano lesson and not during or at a soiree. ${ }^{43}$ Still, although the mentioned quotation has a different background, it shows one side of Clara Schumann's character. Despite the knowledge that Clara Schumann and Luise Adolpha Le Beau had a rivalling relationship, Le Beau's statement may offer a grain of truth. However, it must be said that amusement was only seen as a talent and was only appreciated in France rather than in Germany. Therefore, even at the home of Elisabeth von Herzogenberg and Luise Reichhardt the ambience was modest and serious. This was typical for the artistic-middle-class salons in Germany. In contrast to that, the aristocratic salons were lively and friendly. It seems that the salonnières in Germany wanted to receive the reputation of virtue by severity, precision and academic passion. ${ }^{44}$

\section{Summary and Prospects}

To sum up, after researching and writing this article, it is clear what Clara Schumann wanted her salons to be liked. Her aim was to spread the Romantic music, especially the music of Johannes Brahms, Felix Mendelssohn Bartholdy and her husband Robert Schumann. Additionally, her purpose was to support young and ambitions musicians and composers such as Nils Wilhelm Gade and Johannes Brahms. In order to achieve her goals, she used her social network. Clara and Robert Schumann certainly did not like too much restlessness, laughter, chatter and non-seriousness. Sometimes their soirees were arranged in a disciplined and serious manner. In their eyes, their soirees served a cultivation of music. However, as previously mentioned, contradictory statements exist, due to which some questions arise.

\footnotetext{
42 "She does not have a kind heart, says everything in an impatient tone, even brutal, so that I cannot feel a great affinity." See V. Beci, Musikalische Salons..., op. cit., p. 71.

43 See L.A. Le Beau, Lebenserinnerungen einer Komponistin, p. 48.

44 See V. Beci, Musikalische Salons..., op. cit., pp. 71-72.
} 
Were these parties really as bad, strict and little entertaining as it was said? Or are Veronica Beci's statements only exaggerations? Clara and Robert Schumann's diaries report of soirees where the Schumanns were guests and they often complained about chitchat, disturbances and non-seriousness; but that does not necessarily mean that their soirees were strict, less entertaining and academic. Other questions deal with further details of the hold soirees of the Schumanns: What kind of music was played? Who were the composers? At what time did they meet and how long did they play and sing together? These are still important questions to address, although they cannot be fully answered with today's sources and might not ever be completely answered in the future.

The lack of source material, especially diaries and memoires leaves many questions open. Even though only few questions have been answered and many more questions have come up a short insight into the salons of the Schumann's has been given and hopefully a clear picture of the salons of the Schumann's can be given in the future. This article is just the first attempt at this subject and more research is necessary and more sources still have to be found.

\section{Abstract}

Clara and Robert Schumann were connected very closely to the culture of the musical salons serving young and ambitious musicians and composers. Clara Schumann's life is documented very well, but there is only a very small amount of literature dealing with her activities in the musical salon. This paper aims at providing an insight into the different circles Clara as well as her husband organised. The existent and non-existent source material is discussed and, by doing that, the current state of research on this subject is elaborated. Furthermore, this paper endeavours to point out the difficulties of research on this topic. That part is followed by a closer look at the characteristics of the private circles of the Schumanns during their years of marriage and the years after Robert Schumann's death from 1856 to 1896. 


\section{Keywords}

Clara Schumann, musical salon, $19^{\text {th }}$ century, Germany

\section{Abstrakt}

\section{Badania nad salonami muzycznymi Clary Schumann i związane} $\mathrm{z}$ tym problemy

Klara i Robert Schumannowie współtworzyli kulturę salonów muzycznych, pomagając tym samym młodym i ambitnym muzykom i kompozytorom. Życie Klary Schumann zostało bardzo dobrze udokumentowane, jednakże tylko kilka opracowań traktuje o jej działalności w zakresie prowadzenia salonu muzycznego. Niniejszy artykuł daje wgląd w kręgi towarzyskie Klary i jej męża. Biorąc pod uwagę aktualny stan badań, a także uwzględniając związane $\mathrm{z}$ tym trudności, omówiono zachowany i utracony materiał źródłowy. Tę część poprzedza charakterystyka towarzyskiej sfery Schumannów w okresie trwania ich małżeństwa, a także od śmierci Roberta Schumanna (1856) do $1896 \mathrm{r}$.

\section{Słowa kluczowe}

Clara Schumann, salon muzyczny, XIX wiek, Niemcy

\section{Bibliography}

Beci V., Musikalische Salons. Blütezeit einer Frauenkultur, Zürich 2000. Hensel F., Tagebücher, ed. by H.-G. Klein, R. Evers, Wiesbaden 2002. Hofmann R., Die Beziehung zwischen Theodor Kirchner und Robert und Clara Schumann, in: "Neue Bahnen". Robert Schumann und seine Musikalischen Zeitgenossen, Mainz 2002 (Schumann Forschungen 7), pp. 154-163.

Höcker K., Clara Schumann. Die große Pianistin ihrer Zeit. Die Lebensgefährtin Robert Schumanns. Die Freundin von Johannes Brahms, Berlin 1975. 
Kienzle U., Robert und Clara Schumann in Frankfurt, Frankfurt am Main 2010 (Mäzene, Stifter Stadtkultur. Schriften der Frankfurter Bürgerstiftung und der Ernst Max von Grundelius-Stiftung 8).

Klassen J., Clara Schumann. Musik und Öffentlichkeit, Köln 2009 (Europäische Komponistinnen 3).

Le Beau L.A., Lebenserinnerungen einer Komponistin, Baden-Baden 1910, Reprint: Baden-Baden 1999.

Litzmann B., Clara Schumann. Ein Künstlerleben. Nach Tagebüchern und Briefen, Vol. 2: Ehejahre 1840-1856, Leipzig 1920.

Litzmann B., Clara Schumann, Vol. 3: Clara Schumann und ihre Freunde, 3. edition, Frankfurt am Main 1910.

Nauhaus G., Bodsch I. (Ed.): Robert und Clara Schumann Ehetagebücher 1840-1844, 2. edition, Bonn 2013.

Nauhaus J.M., 1863-1873 Baden-Baden, in: Schumann-Portal, [online] http://www.schumann-portal.de/Baden-Baden_1863-1873.html [accessed: 28.07.2016].

Reich N.B., Clara Schumann Romantik als Schicksal. Eine Biographie, Hamburg 1991.

Schleuning P., Fanny Hensel geb. Mendelssohn. Musikerin der Romantik, Wien 2007.

Schumann E., Claras Kinder. Erinnerungen, Köln 1995.

Schumann F., Erinnerungen an Clara Schumann, „Neue Zeitschrift für Musik", Vol. 84/9, pp. 69-73.

Schumann R., Tagebücher, Vol. 2: 1836-1854, ed. by G. Nauhaus, Frankfurt am Main 1987.

Schumann R., Tagebücher, Vol. 3: Haushaltsbücher, ed. by G. Nauhaus, Leipzig 1982.

Steegmann M., Clara Schumann, Hamburg 2007.

De Vries C., Die Pianistin Clara Wieck-Schumann. Interpretation im Spannungsfeld von Tradition und Individualität, Mainz 1996.

Wilhelmy-Dollinger P., Die Berliner Salons. Mit historisch-literarischen Spaziergängen, Berlin 2000. 